\title{
REFLEXÕES TEÓRICO- METODOLÓGICAS SOBRE OS DADOS DA EXPLORAÇÃO DO TRABALHO INFANTIL: OU COMO TRANSFORMAR CRIANÇAS E JOVENS EM NÚMEROS
}

\author{
Maurício Roberto da Silva ${ }^{1}$ \\ "Os números aparentemente são concretos,
} mas na verdade são abstratos”. Milton Santos (2002)

Resumo: O objetivo deste texto é, devido à multidimensionalidade da problemática, formular questões, buscando possíveis respostas para a "dança dos números" estatísticos dos órgãos oficiais, não focalizando, necessariamente, a centralidade do texto nas análises estatísticas dos números absolutos de forma mais densa e qualitativa. O intento é instigar à comunidade acadêmica, políticas públicas, movimentos sociais e sindicatos, mais com questões do que com respostas, a problematizarem os números sobre a exploração do trabalho de crianças e jovens. Para tanto, tomo como referência algumas pesquisas anteriormente produzidas: (LIEBEL, 2003, 2006 ; VIELLA, 2008; VIELLA; CONDE (2010); GARCIA, 2010; SILVA, 2003), buscando tornar a reflexão teóricometodológica, de caráter mais "teórico-prático", em termos de exemplos concretos de análises críticas já realizadas. As conclusões que cheguei apontam para a o desafio dos intelectuais da universidade e fora dela, quanto à necessidade, de superar o "falso dualismo"entre quantidade $\mathrm{e}$ qualidade; no sentido da análise qualificada e crítica das estatísticas oficiais e "contra o uso político das estatísticas"sobre a exploração do trabalho infantil, em suma, contra manipulação desses dados para fins eleitoreiros e ideológicos no âmbito do "neoliberalismo social".

Palavras-chave: Trabalho infantil. Exploração. Estatística. Erradicação. Políticas públicas. 


\section{Formulando perguntas e buscando respostas}

O título deste texto indica as minhas intenções de pesquisa atuais e futuras, diante da problemática da exploração do trabalho infantil e do "uso político das estatísticas" (SANTOS, 2002), acerca da exploração do trabalho infantil. A intenção primeira do texto é desvendar a névoa de fumaça ideológica que se traduz na "pseudoconcreticidade" (KOSIK,1975) e encobre os dados estatísticos oficiais. Para isso, trago um debate sobre a dimensão dialética quantitativo-qualitativa no trato para com a estatística. Em termos de recorte e delimitação, o ensejo do texto é contribuir para o debate que envolve questões teórico-metodológicas, de natureza crítica, apontando para questões de natureza epistemológica, ontológica e ideológica, subjacentes aos documentos oficiais estatísticos nacionais e internacionais. Portanto, não se trata de fazer análises qualitativas dos números absolutos presentes nos dados estatísticos da exploração do trabalho infantil. Ao invés desse procedimento, tomo como referência algumas pesquisas anteriores (LIEBEL, 2003; LIEBEL, 2006; VIELLA; VIELLA e CONDE (2010); GARCIA, 2010; SILVA, 2003), buscando tornar a reflexão teórico-metodológica, de caráter mais "teórico-prático", em termos de exemplos concretos de análises críticas já realizadas. Na esteira do pensamento deixado por esses autores, busco realizar, simultaneamente, um debate articulado à dimensão dialética quantitativo-qualitativa no trato para com a estatística, ensejando refletir sobre a atualidade de algumas questões teóricometodológicas, de natureza crítica, já realizadas.

Justifico a escolha dessas pesquisas, por serem produções acadêmicas realizadas a partir de 2000 e pelo fato de contemplarem a perspectiva do materialismo histórico-dialético. São pesquisas fundamentadas nos pressupostos ético-políticos da ontologia marxiana, que têm como eixo epistemológico, ontológico e ideológico, a práxis. Estes textos problematizam os discursos e os dados estatísticos oficiais sobre a redução da exploração do trabalho infanto-juvenil e a forma como maquiam as vicissitudes do neoliberalismo. As produções eleitas como referência para esse texto, expõem o caráter fetichista e apocalíptico dos discursos e cifras, cujo resultado induz que a exploração do trabalho infantil diminui à medida que as crianças e jovens e suas 
famílias estão sendo atendidas pelo Programa Bolsa Família ou pela fiscalização realizada pelo Ministério do Trabalho e Emprego.

O objetivo central é, devido à multimensionalidade da problemática, formular questões, buscando possíveis respostas para a "dança dos números" estatísticos dos órgãos oficiais, não focalizando, necessariamente, a centralidade do texto nas análises estatísticas dos números absolutos de forma mais densa e qualitativa. Quando isso acontece, é apenas com a intenção de ilustrar, sob a forma de exemplo, como a "ditadura das sondagens" (FABRA,1995) vem pondo em "xeque" a credibilidade desses dados, oriundos dos órgãos oficiais e internacionais, ao tratar seres humanos, meramente como números! A ideia é instigar a comunidade acadêmica, as políticas públicas, os movimentos sociais e sindicatos, mais com questões do que com respostas, a problematizarem os números sobre a exploração do trabalho de crianças e jovens. Afinal, o que está em pauta, já há algum tempo, é o mito ou "propaganda enganosa e aparente" (VIELLA, 2008; VIELLA e CONDE, 2010); da "manipulação dos dados" (LIEBEL, 2003) e do "marketing estatístico"(SILVA, 2003). Este mito pode ser consubstanciado, tendo como "pano de fundo" crítico, a ideia de que "a ideologia econômica neoliberal distorce, disfarça e manipula os dados da pobreza mundial, com o fim único de perpetuar o capital". (CHOSSUDOVSKY, 1999).

Tudo isso se passa num processo de simbiose com a mídia, cujo resultado culmina com a teatralização e "espetacularização do real" (VIELLA, 2008), cujo pano de fundo fomenta, de forma contraditória, uma espécie de "banalização" e "visibilidade" da ideia de infância empobrecida (SILVA, 2002a). Essa espetacularização do real, inculcada pelo fetiche das estatísticas, tem suas raízes na chamada "sociedade do espetáculo" (DEBORD, 1997).

Neste contexto, um argumento importante para a delimitação do texto, foi a "pergunta-síntese" que fiz entre 1996 e $2003^{2}$, durante o processo de produção da tese e do livro: 'É possível erradicar pela raiz a exploração do trabalho infantil no âmbito do capitalismo?". Esta pergunta mais genérica traz, subjacente, outras questões instigantes de pesquisa: por que os dados estatísticos são tão contraditórios? Como pode ser possível a diminuição ou até o "desaparecimento" da exploração do trabalho infantil (exemplo da cana-de-açúcar), se cresce a cada dia o número do desemprego 
estrutural em todo o planeta? Decorrente desta questão, surge outra: Como o discurso, "discurso abolicionista" das fontes nacionais e internacionais de pesquisa (GARCIA, 2010), se coloca diante da nova "morfologia do trabalho" (ANTUNES, 2007), que é gestada no processo de reestruturação produtiva das políticas neoliberais e do cenário de desindustrialização e privatização? Dito de outra maneira mais delimitada: como é possível que medidas emergenciais e precárias de "inclusão social", possam ter impacto radical sobre o mundo do trabalho, em regiões como a Zona da Mata canavieira ${ }^{3}$, se um terço da força humana de trabalho humano disponível, em escala planetária, ou se encontra exercendo trabalhos parciais, precários, temporários, ou já vivenciava a barbárie do desemprego?

Destaco que este processo de indagação investigativa, no que pese essas preocupações com a dimensão positivista das estatísticas, já vem me intrigando há bastante tempo, sobretudo, quando está em jogo, além da manipulação dos dados, uma "cegueira estatística" (FABRA, 1995). Digo isso, porque, percebi nas participações em bancas de mestrado e doutorado, que grande parte dos pós-graduandos e de seus orientadores, por um lado, negavam os dados estatísticos, justificando suas pesquisas como meramente "qualitativas". Por outro lado, usavam de forma meramente ilustrativa e sem críticas, as cifras estatísticas contidas nos documentos oficiais, sem sequer desconfiar ou "decifrar", a natureza dos dados, considerando os seus pressupostos epistemológicos, ontológicos e ideológicos.

Neste sentido, as reflexões sobre a natureza dos dados (qualitativa e quantitativa), têm como base o materialismo histórico-dialético, a partir das leis sociológicas que caracterizam a vida em sociedade, de sua "evolução histórica" e da "prática social" dos homens, do desenvolvimento da humanidade diante da trajetória histórica da exploração do trabalho infantil. O método tem como eixo a consideração de suas leis: lei da interação universal (da conexão, da mediação recíproca de que tudo existe), lei do movimento universal (que implica integração entre movimento interno e externo, promovendo o universal), lei da unidade dos contraditórios, lei da transformação da quantidade em qualidade (lei dos saltos), lei do desenvolvimento em espiral (da superação), (LEFEBVRE, 1975). A reflexão baseia-se ainda nas diversas categorias: história, estrutura socioeconômica, forças produtivas e classes sociais (as lutas de classe: entre capital e trabalho). Esse movimento dialético implica problematizar 
a totalidade da sociedade e as condições objetivas, que resultam nas estatísticas acerca da exploração do trabalho infantil, em relação às suas contradições, transformação da quantidade e qualidade, as superações (manutenção ou diminuição dos dados). Afinal, o que está em pauta nas ciências sociais e humanas não é o ser humano tratado como número ou como "coisa", mas seres sociais que, de forma precária e perversa, estão imersos, em escala planetária, no processo do trabalho produtivo, na ordem da acumulação flexível, enfim, na crise estrutural do capital.

\section{O que dizem as pesquisas sobre os dados estatísticos da exploração do trabalho infantil?}

Como foi anunciado no início do texto, vou considerar as pesquisas de Viella, 2008; Liebel, 2003; Silva, 2003; Liebel, 2006; Viella e Conde, 2010 e Garcia, 2010. O critério para a escolha desses trabalhos justificase, por se tratar de pesquisas recentes e cujo enunciado, traz de maneira incisiva as críticas ao mito da exploração do trabalho infantil no Brasil e no mundo, nas fontes oficiais nacionais e internacionais (IBGE, OIT, UNICEF e outras). O texto de Viella e Conde (2010), origina-se da tese de Viella (2008) e dissertação de Conde (2007), com o destaque de que, para além de abordar a problemática no mundo e no Brasil, analisam os dados da erradicação em Santa Catarina.

A tese de Viella (2008), intitulada "Fetichismo da infância e do trabalho nos mapas do trabalho infantil", faz uma análise interessante, no Capítulo 3 (p.146), sobre "O trabalho infantil sob as lentes dos organismos nacionais e internacionais". A autora faz um enorme esforço, a partir dos Mapas Indicativos do trabalho Infantil", um de 1997 a 1999 e outro de 2005, para tentar compreender a dança dos dados estatísticos e realizar análises comparativas entre os mapas. No decorrer do capítulo, tece considerações sobre o fetiche dos dados desses organismos, advertindo sobre a dificuldade em se proceder análises por causa dos desencontros das cifras em relação ao número de crianças trabalhadoras no mundo, seu recorte de faixa etária, períodos equivalentes de coleta de dados e outras variáveis.Trata-se de uma tarefa árdua, realizar análises dos números absolutos; o processo é quase que "incontável”. 
Ao fim e ao cabo, a tese de Viella (2008) e o texto de Viella e Conde (2010), chegam à conclusão, com base na análise do Mapa de Indicativos do Trabalho da Criança e do Adolescente (1999 e 2005), que a redução propagada é aparente, pois o aumento da diversificação das atividades desenvolvidas pelas crianças e adolescentes encontrase em perfeita simbiose com as atuais transformações no mundo do trabalho. As novas formas do trabalho coletivo empurraram as crianças do chão da grande indústria para inúmeras atividades invisíveis à fiscalização. Esse fato demonstra que

a luta para a erradicação do trabalho infantil e o alardear de sua redução deixam evidentes limites dessas propostas que representam apenas uma maquiagem (grifo meu) na feição com que se mostra e no grau da exploração no qual se realiza; expondo, assim, a face oculta do capitalismo que gera pobreza e a inserção precoce das crianças no trabalho produtivo, deixando aberta a ferida da essencialidade do fenômeno trabalho infantil para o metabolismo do capital (VIELLA, 2008, p. 6).

Em síntese, Viella (2008, p.202-203) conclui a tese com o seguinte pensamento:

[...] Por mais que se tente atualizar os Mapas dos indicativos do trabalho Infantil e se avance nessa direção, a capacidade que adquiriu o capital de se mover, invadir todas as fronteiras e firmar cada vez mais seus contornos mercadológicos mostra as limitações de tal atividade.[...] Afirmar, como faz o Relatório Global 2006, que o fim do trabalho infantil está próximo, é ter uma visão muito simplificada do real; é ignorar que num mundo onde continuam reinando as mercadorias, é impossível falar de erradicação do trabalho infantil (grifos meus), já que ele é inerente ao sistema capitalista (grifos meus). Aí está o fetiche: eliminar o trabalho infantil sem que se elimine o sistema que o gera (grifos meus). Os próprios Mapas Indicativos, quando revirados ao avesso, revelam aumento significativo do trabalho infantil em todos os setores da economia (grifos meus), destacadamente na indústria, contrariando os discursos que propalam sua redução nesse setor (grifos meus). Colocam em xeque, ao mesmo tempo, o discurso 
laudatório da OIT que, no Relatório Global, anuncia que a viragem está próxima (grifos meus), inclusive, estabelecendo um prazo de dez anos para que sejam eliminadas as piores formas, sem perder de vista que o objetivo último é acabar com todo o trabalho infantil (grifos meus).

Viella e Conde (2010), no texto "O mito da redução da exploração do trabalho infantil no Brasil e em Santa Catarina", buscam problematizar o discurso do governo federal sobre a redução do número de crianças trabalhadoras no Brasil, entre os anos de 1995 a 2002, com base na análise do Mapa de Indicativos do Trabalho da Criança e do Adolescente (1999 e 2005), nos procedimentos metodológicos utilizados na elaboração dos mapas e ainda, apontando os limites da fiscalização do Ministério do Trabalho (grifos meus); utilizam-se, também, da análise detalhada das atividades realizadas por crianças e os municípios de Santa Catarina.

$\mathrm{Na}$ conclusão das autoras, a redução dos dados é apenas uma fachada. Este fato, assinala para a evidência de que a diminuição do número de crianças e jovens trabalhando, depende muito do método empregado pelas estatísticas e dos interesses político-eleitoreiros nas mudanças superficiais e emergenciais de uma determinada região.

As críticas das autoras supracitadas ao fetiche dos dados estatísticos, podem ser confrontadas com as críticas de Silva (2002b) ao UNICEF, na sua resenha "Entre a visibilidade e a banalização: Uma celebração da infância no mundo ou um Festival de The Collors Of Benetton?". Neste texto, o autor traz, já iniciando uma crítica , ainda que incipiente, os dados estatísticos sobre a "Situação Mundial da Infância/1997", publicados pelo UNICEF, e tecendo algumas considerações: o fato do UNICEF ser portador de alto reconhecimento nacional e internacional, principalmente, pelos programas e ações contra a exploração do trabalho infantil, mortalidade infantil, prostituição infantil, violência contra crianças e outras; utilizar-se da bandeira da denúncia fazendo grande alarde sobre os dados estatísticos (grifos meus) acerca dos maus-tratos da criança no mundo. Sua imagem ligada à "caritas", pode ser exemplificada com o fomento e patrocínio de 
campanhas beneficentes do tipo Criança-Esperança" da Rede Globo de Televisão (grifos meus). Estas concepções terminam por veicular a ideia da "criança-coitadinha", identificada com sentimentos de pena, compaixão e dó. O discurso do UNICEF é ardiloso e na questão da exploração do trabalho infantil, culpa os empresários sem, entretanto, nomear os culpados (grifos meus). Deste modo, arvora-se no direito de não fazer críticas radicais ao modelo neoliberal (grifos meus), disfarçando, assim, suas afinidades com os conluios, pactos, consensos e planos de ajuste estrutural do FMI e Banco Mundial e outras instâncias do poder capitalista mundial (grifos meus) (SILVA, 2002a, p.154-155).

De acordo com Manfred Liebel (2003), informe da OIT afirma que o número de "trabalhadores infantis" diminui, sobretudo, na América Latina e no Caribe, no transcurso de quatro anos, que haveria se registrado uma redução de dois terços (parágrafo 29). Nestes termos, diante da audácia de afirmações como essas, os conhecedores latinoamericanos da situação acerca do trabalho infantil, não deixam de ficar assombrados e estarrecidos. A esse respeito, o autor traz vários exemplos apontando,num artigo do jornal Paraguay, de maio de 2006, o escritório local do UNICEF sinalizou que o número de "crianças economicamente ativas" aumentou em aproximadamente, 56.500 nos últimos anos. Da mesma forma, também o Ministério do Trabalho argentino, realizou uma enquete, cujos resultados concluíram que, em nível nacional, o trabalho infantil "aumentou de maneira alarmante". Em contrapartida, um informe do Escritório Regional Andino de Terre des Hommes, sugere que os dados do informe da OIT, foram manipulados para que suas atividades de luta contra o trabalho infantil aparecessem de forma mais positiva (grifos meus).

Este autor, ao tratar da questão da legitimidade dos dados da OIT sobre o "trabalho infantil", afirma que há controvérsias sobre a verossimilhança dos dados acerca das categorias "trabalho infantil tolerável", "trabalho infantil intolerável", "piores formas de trabalho infantil", como já mencionamos anteriormente (LIEBEL, 2003). Isto significa dizer que, para além dessas categorias questionáveis, também se impõe o questionamento sobre a falta de provas empíricas. Há, neste sentido, dúvidas sobre as fontes e os métodos de medição, sobre os quais estão fundamentados os dados indicados e, além do mais, 
quais são os problemas práticos que surgiram na determinação do número de crianças trabalhadoras em nível mundial, segundo critérios uniformes. Posto isto, analisando de forma mais rigorosa, percebe-se que os dados em questão se baseiam em fontes muito diferentes que, por sua vez, se fundamentam em conceitos estatísticos que não são comparáveis. Mesmo assim, a base de dados é muito escassa, ou seja, as cifras quanto ao número de "trabalhadores infantis", para o ano de 2004, por exemplo, estão baseadas somente em dados de 31 países e na maioria, do ano 2000 (LIEBEL, 2003). De acordo com o autor:

Los datos en los que se fundamenta el informe tampoco permiten determinar si la magnitud del trabajo infantil realmente ha disminuido entre los años 2000 y 2004. Primero, sólo se tiene datos de 17 países y referentes a dos años diferentes. En algunos casos, esta información abarca un periodo de tiempo tan corto que es totalmente insuficiente para deducir o identificar alguna tendencia de ella. Por ejemplo, las estadísticas para Kenia se refieren a los años 1999 y 2000. Segundo, en el caso de la India, por ejemplo, sólo se tiene datos de los años 1994 y 1999/2000, lo que, obviamente, no permite sacar ninguna conclusión para los años 2000 a 2004. Los datos para Brasil, que se refieren a los años 1998 y 2003, son los únicos que se acercan al período del 2000 al 2004. (p.3)

Toda essa oscilação ou dança dos números estatísticos se deve a uma harmonização dos métodos de medição em coordenação com as instâncias internacionais. Para além deste tipo de procedimento duvidoso, na avaliação das taxas de exploração do trabalho de crianças, pode-se exemplificar, a partir da experiência de ONGs e movimentos de crianças trabalhadoras, as quais contradizem as boas notícias de progresso em prol da diminuição dos índices do trabalho infantil, grande parte delas, carecendo de credibilidade, provas empíricas e de força comprobatória analítica. Todo esse projeto ardiloso de erradicação, desenvolvido pela OIT-IPEC é, portanto, respaldado com a denúncia vazia e abstrata sobre os efeitos que têm os processos de globalização neoliberal e das estratégias político-econômicas como as liberalizações, as desregulamentações e as privatizações sob o trabalho de meninos e 
meninas. Diante dessas questões, de caráter político-econômico, a OIT se posiciona de forma bastante nebulosa, apresentando como alternativa apenas uma suposta vontade para uma globalização justa sem, todavia, apontar com clareza e objetividade para os caminhos em direção às transformações sociais em nível planetário (LIEBEL ${ }^{4}$, 2003; SILVA, 2003).

As críticas de Liebel tem fundamento, pois ao buscar a atualização dos dados estatísticos da exploração do trabalho de crianças e jovens no Brasil, percebe-se que os dados da OIT, pelo menos de 2000 a 2008, eram de 250 milhões de crianças em todo o mundo. Mas na atualidade, curiosamente, esses dados caíram para 210 milhões. A pergunta é: Como? De que maneira? O que mudou no metabolismo global do capitalismo que possibilitou uma mudança tão brusca na dança dos números? Será que os governos, de fato, conseguiram acabar com a exploração de crianças, diante do grande índice de desemprego dos adultos? Ademais, será que as políticas de geração e distribuição de renda, pelo caráter emergencial destas, conseguem alterar radicalmente as cifras da exploração do trabalho infantil?

Nesta mesma direção, Garcia $(2010)^{5}$ critica OIT, UNICEF e o Banco Mundial, em torno do debate sobre a erradicação do trabalho infantil, chama de "Extraña Dictadura" as falsas promessas e ilusões vendidas por estas organizações que continuam profetizando a erradicação do trabalho infantil em 2016. De acordo com o autor, esses organismos e seus discursos neoliberais não têm consistência para por fim às classes sociais, nem aos grupos do poder econômico que governam o mundo, pelo fato de haver, na atualidade, milhões de seres humanos condenados à insignificância e ao desespero. E tudo isso porque, longe de questionar o modelo econômico, as políticas neoliberais têm servido para camuflar e suavizar os seus efeitos negativos, o aprofundamento da demissão de seus beneficiários sobre o aspecto depredador deste modelo e o empobrecimento das vidas humanas. Neste sentido, há a necessidade de se construir movimentos contra hegemônicos, visando recriar "as formas coletivas de organização" por entender o trabalho como uma fonte da humanidade, que se constitui na sustentação explícita de todo princípio formativo e educativo. 
Com base nesses pressupostos, Garcia (2010) propõe que se organize o trabalho de crianças e adolescentes para que, de forma mais precoce, familiarizem-se com suas obrigações e assim, possam desfrutar "de las satisfacciones incomparables que de ello se derivan; Propone la suma millonaria de los costos y los beneficios de los 60 millones de dólares sea distribuida de manera más equitativa en programas de educación y trabajo" (p.10). Em suma, enfatiza que as políticas neoliberais, longe de questionarem o modelo econômico, "han servido más bien, para amortiguar y edulcorar sus impactos negativos, profundizar la resignación de sus beneficiarios y tranquilizar la "mala conciencia" del modelo depredador y empobrecedor de vidas humanas" (p.10), aspectos pertinentes para se situar o discurso da erradicação do trabalho infantil. Apesar das contribuições do texto supramencionado, considero perigoso defender, em nome do trabalho educativo e formativo, a inserção militante das crianças, tendo em vista um suposto protagonismo delas para que, assim, possam, de forma precoce, tomarem consciência da exploração em que vivem. Esta posição é extremamente ambígua, podendo representar "um tiro no pé", no sentido de correr os riscos de continuar a reproduzir e perpetuar a dimensão do trabalho abstrato (trabalhar unicamente para manterse e satisfazer as meras "necessidades" ou trabalho socialmente necessário $)^{6}$, sem a superação radical do modo de produção capitalista. A proposta é interessante, desde que se tenha clareza de que as lutas pelo trabalho como princípio formativo e educativo estejam articuladas com as lutas contra o trabalho abstrato dos adultos, quer seja no Brasil, América Latina e em todo o planeta. $\mathrm{O}$ argumento do protagonismo, a partir dos pesquisadores do IFEJANT, pode ser relativizado, se levarmos em consideração o contexto específico e legítimo das lutas contra o capital, que se travam no interior desses movimentos sociais na América Latina, pois, afinal, como defendemos na perspectiva marxiana "o critério de verdade é a prática social".

A "extraña dictadura" (GARCIA, 2010) ou a "ditadura das sondagens" (FABRA, 1995), caminham um pouco na linha das críticas que faz Chossudovsky (1999, p.34-35) às instituições internacionais perpetuadoras do sistema econômico global. Este autor afirma que a ideologia econômica "distorce" as causas da pobreza mundial ao 
"manipular"os números sobre esta situação. Segundo ele, isso vem aumentando porque o discurso dominante tem aumentado sua influência nas instituições acadêmicas e de pesquisa pelo mundo afora, impondo o pressuposto de que a realidade social e econômica deve ser vista através de um único conjunto de relações econômicas fictícias, cujo objetivo é dissimular as "manipulações do sistema econômico global". Neste âmbito, o Banco Mundial desempenha um papel-chave, ao promover pesquisa sobre as chamadas "dimensões sociais do ajuste". Essa dimensão ética, consubstanciada pelas categorias subjacentes ao seu discurso, como por exemplo: diminuição da pobreza, questões ligadas ao gênero, equidade etc, emprestam uma "face humana" às instituições de Bretton Woods e, consecutivamente, uma aparência de compromisso com as mudanças sociais. Em suma, através da manipulação das estatísticas de renda, as cifras do Banco Mundial servem ao útil propósito de representar o pobre nos países em desenvolvimento (CHOSUDOVSKY,1999,p.34-35) e, ironicamente, ao mesmo tempo, num defensor da erradicação da miséria.

Essas políticas têm como pano de fundo as "políticas econômicas", consideradas por alguns estudiosos (CHOSSSUDOVSKY, 1999; FORRESTER, 1997; GALEANO 1999; CHOMSKY, 1997) como uma determinação clássica do Fundo Monetário Internacional e do Banco Mundial, cujo objetivo é fazer com que as economias dos países periféricos funcionem na lógica da acumulação e das necessidades do capital internacional. Quanto ao Banco Mundial, não se pode desconsiderar que se trata de uma instituição paradoxal, ou seja, seus recursos, a natureza de seus objetivos e o alcance da sua ação são de caráter essencialmente público, porém, sua prática é predominantemente a de um banco comercial privado (ARRUDA,1996). Pode-se compreender por que os discursos e os números estatísticos são construídos, tendo como elemento ideológico fundante, a falsa promessa neoliberal de ascensão social, "inclusão" e "cidadania", subjacente às diversas ações e programas das políticas sociais e públicas do atual governo brasileiro (trabalho, educação, previdência e outras)

À guisa de comparação, outros exemplos do período de construção da minha tese se seguem: enquanto os relatórios do UNICEF e OIT 
(1999), apontavam para os números de, aproximadamente, 250 milhões de crianças trabalhando em todo o mundo, os "Tribunais Internacionais contra o Trabalho Infantil", realizados, respectivamente,no México(1998) e São Paulo(1999)7, indicavam, na época, para cifra de mais de 300 milhões, argumentando, inclusive, que no ano 2004, seriam 400 milhões de crianças enquanto força humana barata de trabalho, em consequência do crescente desemprego em todo o mundo. Também, quando iniciei a pesquisa, os dados do Centro Josué de Castro, datados de 1995, indicavam que havia 50.000 crianças, na faixa de 7 a 14 anos, trabalhando nos canaviais de Pernambuco. Hoje, passados quinze anos, há controvérsias de que, supostamente, não existe mais esse número de crianças trabalhando, considerando os programas de inclusão precários, isto é, de caráter emergencial e assistencialista do Governo.

É por essas razões que se situam em torno do mito da erradicação da exploração do trabalho infantil, que Carvalho (2008), conclui em seus estudos que o trabalho precoce e em condições adversas não poderá ser erradicado enquanto permanecerem intocadas as suas maiores determinações, como a concentração da propriedade da terra e a subordinação econômica, que afetam os pequenos produtores, a carência de políticas sociais que possam apoiar melhor a reprodução social dos trabalhadores e, principalmente, as condições de mercado de trabalho que permitem uma perversa constituição das relações de trabalho e uma extrema exploração da mão-de-obra, tanto dos adultos como das crianças.

Seguindo as conclusões dos autores supramencionados, Silva (2003, p. 37), ensaia uma crítica ao fetiche dos dados estatísticos, ao fazer a seguinte questão: exploração do trabalho infantil: o que vale mais, o número e/ou o ser humano? Nesse imbróglio, os discursos e dados estatísticos, consideram, para efeito de propaganda política, meramente, o quantitativismo exacerbado. Nessa dimensão, o ser humano é, ontologicamente, tratado como número, na lógica da racionalidade instrumental do cálculo e do "fetiche" dos percentuais estatísticos. Em relação à exploração do trabalho infantil na Zona da Mata canavieira pernambucana, afirma que, apesar do "marketing estatístico" do Governo Federal, não é possível erradicar a exploração do trabalho de crianças e jovens, sobretudo, numa região historicamente marcada 
pelas relações de trabalho escravagistas da propriedade fundiária. O autor afirma que não é possível extirpar este tipo de exploração pela "raiz", considerando que são falsas as promessas neoliberais pelo fim da exploração do trabalho de crianças e jovens, pois afinal, a exploração é inerente ao modo de produção capitalista. E conclui, [...] enquanto o ser social estiver imerso no reino da necessidade e sob a regência da exploração generalizada e da potência estranha que o domina, não é possível, radicalmente, falar-se em emancipação da condição humana, da infância e da cidadania ${ }^{8}$ (SILVA, 2003, p. 37).

\section{Exploração do trabalho infantil: o que vale mais o número e ou o ser humano?}

[...] As estatísticas sociais se apóiam naturalmente nas "variáveis do Estado", o juízo comum utiliza informações de diferentes tipos. Isto estabelece o problema das relações entre estas diferentes formas de conhecimento e, em última instância, de sua legitimidade (THÉVENOT,1995).

As pesquisas supramencionadas trazem no bojo de seus pressupostos teórico-metodológicos e conclusões que apontam, a "espetacularização do real" e do "fetiche do método". Como se pode perceber, há, de caráter ideológico, uma tendência à manipulação dos dados, com fins de reproduzir e manter o metabolismo do capital. Esse processo se dá, primordialmente, pela via do projeto de sociedade neoliberal, que tem implementado políticas públicas de natureza emergencial, clientelista, eleitoreira, enfim, de inclusão precária. Neste sentido, o desafio que se coloca para os "intelectuais transformadores e revolucionários (PETRAS, 2005) é abstrair dos números e dos discursos a possibilidade de fazer deles um processo de construção de uma "ciência militante e da contestação, conforme nos ensinou Florestan Fernandes (1980).Trata-se, portanto, de realizar uma "prática política radical", um pensamento e ação militantes, que sejam capazes de reelaborarem as ideias que procedem da academia e dos estudos sistemáticos sobre o Brasil e América Latina (FERNANDES,1995). Diante dessa realidade, cumpre lembrar que os fatos e dados numéricos 
"não falam por si mesmos", necessitando de nossa capacidade crítica de polarização e da desconstrução da ideologia subjacente a eles. Urge, portanto, diante da falseabilidade e mudez dos dados, admitir que eles permanecem mudos até serem corretamente interrogados (ordenados e analisados) com o auxílio de uma teoria consistente com o conjunto da realidade social capitalista (CASTRO, 2003[s/p];VIELLA, 2008).

Nas páginas que se seguem, tento problematizar sobre o papel da estatística e, consequentemente, da importância de "decifrar" de maneira crítica a "cifra". Trata-se de reflexões introdutórias no debate novo-velho acerca dos encontros e desencontros entre os paradigmas quantitativo e qualitativo.

\section{Reflexões sobre as fontes estatísticas}

Quanto à sua etimologia, o termo estatística deriva do neolatim statisticum collegium ("conselho de Estado") e do italiano statista ("estadista" ou "político"). O alemão Statistik, introduzido pelo primeira vez por Gottfied Achenwall (1749), designava, originalmente, a análise de dados sobre o estado, significando a "ciência do Estado" (então chamada aritmética política (political arithmetic) em inglês). A palavra adquiriu o significado de coleta e classificação de dados em geral através de Sir John Sinclair. Nestes termos, o propósito original da Statistik era fornecer os dados a serem usados pelo governo e outras organizações. A coleta de dados sobre estados e localidades continua, em grande parte, através de órgãos estatítiscos nacionais e internacionais. Particularmente, os censos fornecem informação regular sobre as populações. Deste modo, pode-se dizer que é, na sua origem, uma "ciência do Estado". Um exemplo disso é que o impulso das estatísticas sociais, no século XIX, baseou-se na sua capacidade de estabelecer leis sobre os fatos da sociedade que poderiam justificar medidas políticas, criminalidade, saúde, educação e outras (THÉVENOT,1995), seguindo seu curso até os dias atuais.

Grosso modo, a estatística pode ser compreendida como um conjunto de métodos utilizados para obter, organizar e analisar informações numéricas. Sua importância está em seu vasto campo de aplicação, cujos conhecimentos são usados nas ciências exatas, ciências sociais 
e humanas, em diversas áreas, tais como: Engenharia, Educação, Psicologia, Sociologia e outras. (WADA e VIEIRA, 1998, p.9). No entanto, há de se fazer uma distinção entre "estatísticas" e "estatística". As estatísticas são os resultados da observação. Ao passo que a estatística nos permite obtê-los e tratá-los, fato este que nos faz constantemente esquecer que os fatos numéricos não provêm de uma simples operação de medida, os fatos numéricos são construídos e a observação é uma definição do objeto. As estatísticas surgem como uma medida dos diferentes aspectos da realidade. Entretanto, temos que questionar se as cifras são verdadeiras ou falsas, pois sobre elas paira a ideia de "desconfiança" sobre o processo de cristalização da exatidão (BESSON,1995).

Talvez por isso, haja, de um lado, uma espécie de "demonização" e, de outro, um fetiche que tem levado muitos cientistas sociais, principalmente, no campo econômico e social, a acreditar e "consumir" os dados estatísticos oficiais, sem, contudo, abstrair o "uso político" que o Estado faz desses dados (SANTOS 2002; BESSON, 1995). No âmbito disso tudo, destaca-se a questão da "credibilidade" das estatísticas. Essa "credibilidade" (BESSON,1995), não tem sido posta em "xeque" por grande parte dos intelectuais, de viés positivista, das universidades e de outras instituições de pesquisa. Este fato é curioso, pois, apesar de as estatísticas serem usadas como instrumento de dominação e perpetuação da lógica do capital, há no chamado sensocomum, na maioria das vezes e contraditoriamente, uma insatisfação quanto aos índices dos aumentos de salário e das cifras do custo de vida. Sendo assim, na vida cotidiana, o ser social "pode se rebelar diante das médias e totalizações" (BESSON,1995, p.31-43).

O debate sobre a credibilidade da estatística tende a recuperar o velho debate sobre "quantitativo" e "qualitativo". Neste âmbito, o paradigma da quantificação traz consigo o postulado da "comensurabilidade", cujos pressupostos são difíceis de serem admitidos e seu reducionismo suscita críticas, pelo menos, em parte dos pesquisadores das ciências sociais e humanas. Essas críticas são visíveis, principalmente, na economia política, em cujas instâncias epistemológicas de caráter marxista, têm-se a guerra do valor de uso e do valor de troca (BESSON,1995, p.43). Sob essa lógica, há uma 
crítica ferrenha à "ditadura das sondagens", que opera numa espécie de "cegueira estatística"(FABRA,1995) ou "abuso das estatísticas do homem", cujos inconvenientes, entre outros, são o emprego não crítico dos procedimentos estatísticos e a seleção dos problemas de modo que se adaptem às técnicas estatísticas utilizadas, ao invés de proceder de modo inverso (VERA,1973).

Com efeito, a ideia de Milton Santos (2002) do "uso político da estatística" e da promessa contida no discurso neoliberal pela "erradicação da exploração do trabalho infantil, circunscreve-se na perspectiva marxiana do fetiche (VIELLA, 2008; GARCIA, 2010). Aliás, o fetiche dos paradigmas da quantidade ou da qualidade, é uma questão que se situa em diversas posições, ontológicas e ideológicas. Há aqueles que recusam qualquer dimensão quantitativa dos dados da realidade; e aqueles, para os quais, o número "fala por si próprio". Por trás de todo esse imbróglio, [...] a informação estatística é para alguns um fetiche, um objeto sagrado (grifos meus) diante do qual o espírito crítico se detém.[...]. Outros, que se crêem mais prevenidos, têm em relação à estatística uma atitude niilista (grifos meus) de recusa sistemática".(VOLLE apud BESSON, 1995, p.49).

Outro aspecto que trago para o debate, em torno da importância dos dados estatísticos, de natureza filosófico-científica, é questão da relação sujeito-objeto no processo do conhecimento. Nesta perspectiva, o objeto não é tratado como coisa, nem tampouco se impõe ao sujeito do conhecimento (DURKHEIM, 1971), ou melhor, "os fatos sociais devem ser tratados como coisa". Para este autor, o interesse do recurso aos dados estatísticos não se concentra apenas nas formas de raciocínio autorizadas por dados quantitativos (a análise estatística como forma de raciocínio experimental), mas, fundamentalmente, na exterioridade, para o pesquisador dos dados estabelecidos segundo os procedimentos administrativos (MERLLIÉ,1995). Por outro lado, o objeto não se impõe ao sujeito, mas sim é construído na própria análise, através de procedimentos metódicos do investigador e, portanto, não leva em conta a posição durkheimiana de que o pesquisador observa os fenômenos sociais a partir da exterioridade e do distanciamento. Em Weber, a aproximação na relação sujeito-objeto se dá na medida em que pressupõe a consideração da interioridade da ação social em que esta 
é carregada de subjetividade e ao mesmo tempo de racionalidade, quer dizer, de elementos valorativos que caracterizam a ação social. Para o autor, não só o processo em que o sujeito que observa mas também o que é observado (o objeto), representam ações racionais impregnadas de questões valorativas (juízos de valor) e de subjetividade(WEBER, 1992: 104-154).

Pensando para além de Weber e Durkheim, portanto, do ponto de vista do materialismo histórico-dialético, as estatísticas são importantes, caso o pesquisador, leve em consideração que não só o objeto da pesquisa é histórico, mas também os sujeitos da pesquisa, investigador e investigados estão imersos no curso da história, ou seja, a ideia essencial desse método pressupõe a interação do sujeito e do objeto no processo do conhecimento (LÖWY, 1985; BRUYNE, 1991, p.77). A repercussão dessa posição epistemológica é que, para além da alienação, os números devem ser apropriados pelos sujeitos, no sentido de que estes, de maneira crítica, possam humanizar-se para além dos números, reconhecendo-se como diferentes dos objetos, criando e descobrindo significações, elaborando conceitos, ideias, juízos e teorias. Este processo resulta não mais numa relação alheia que o sujeitotrabalhador tem com o processo e o produto do seu trabalho, pois apesar de colocar vida no objeto, este não mais lhe pertence, e sim a outrem (CHAUÍ,1995).

De todo esse debate sobre as estatísticas oficiais, torna-se imprescindível, a meu ver, refletir sobre a dicotomia entre quantidade e qualidade, com vistas a superar os "falsos dualismos" (GAMBOA, 1995), buscando sínteses capazes de darem conta da multidimensionalidade dos fenômenos sociais. Neste sentido, o papel dos intelectuais nas universidades é, fundamentalmente, buscar sínteses capazes de entender a pesquisa como "crítica das fontes de documentação nos domínios econômico, social e político"(SAINTGEORGES,1995). Sob esta ótica, circunscrevem-se as críticas às fontes documentais não-escritas e escritas. Contudo, são nas fontes escritas oficiais e não oficiais que são produzidas as "fontes estatísticas"(SAINT-GEORGES,1995). Para que isso ocorra, é preciso incluir as análises dos procedimentos estatísticos, pensando o processo investigativo no âmbito do "terceiro excluído" ou da síntese dialética. 
Este processo, com base da transformação da quantidade em qualidade e vice-versa se justifica se for levado em conta a crítica, a polarização, a problematização, em suma, as contradições que estão subjacentes nos dados numéricos.

Trata-se de forma contínua e intercomplementar, objetiva e subjetiva, analisar o que está subjacente aos números como, por exemplo: representações, valores, sentidos e significados. Significa desconstruir a concepção positivista de ciência, calcada nos modelos das ciências naturais aplicadas às ciências sociais e humanas, desconsiderando que o objetivo dessas últimas são os seres humanos com suas crenças e práticas sociais, e não a aplicação de um fenômeno amparado pelas "leis científicas". Esses pressupostos terminam por engendrar modelos abstratos de meras descrições e explicações dos fenômenos sociais que produzem regularidades, objetividades e validades conceituais (RICHARDSON, 2010; ANDRÉ,1991; MINAYO, 2007; SILVA, 2003; TRIVIÑOS, 1987; GAMBOA,1995).

\section{A estatística e o empirismo abstrato}

Quando se fala em pesquisa e crítica às diversas fontes documentais, incluindo as estatísticas oficiais, necessário se faz pensar a concepção de ciência que subjaz as pesquisas, assim como, o papel dos intelectuais nas universidades. Vê-se em meio ao turbilhão de violências estruturais, crescer nas universidades, uma plêiade de intelectuais que aderiram à lógica neoliberal da privatização dos meios de produção. Também, observa-se uma tendência cada vez mais crescente do fetiche ao pragmatismo produtivista-quantitativista no limiar das instâncias científicas (CAPES e CNPq), cujas políticas científicas, constituem a base epistemológica e ideológica da chamada "universidade operacional"(CHAUÍ,2003). Este se constitui o lócus privilegiado para produção de fetiches e simulações pós-modernas de construção e veiculação do conhecimento, tendo como pressuposto epistemológico, ontológico e ideológico a acumulação flexível (HARVEY,1998). Esse "sistema de acumulação flexível" traz consigo a ideia de pesquisa como uma atividade da ciência que se traduz em simulações do ato de pesquisar sem relevância pública. Nesta lógica de pensamento e prática 
social, os seres humanos são tratados como "coisa", a partir dos fetiches conferidos às estatísticas realizadas sem nenhum questionamento crítico.

É neste quadro político-acadêmico, dominado pelos intelectuais "produtivos" ou "intelectuais orgânico-conservadores" (GIROUX, 1987) ou "neo-conservadores" (PETRAS, 2005), obviamente com exceções, onde cresce a lógica do fetiche às cifras estatísticas e aos "papers". Todo esse processo, é mediado, ideologicamente, pela "competição" e pela "competência", alimentando, assim, o "Curriculum Lattes" ou o "Currículo Vitae em tempos de empreendedorismo e empregabilidade" (BIANCHETTI,2005).

Diante dessa discussão, o papel dos intelectuais (cientistas sociais), poderia ser o de realizar uma ciência crítica, como fez Florestan Fernandes com sua "sociologia militante" ou "sociologia como contestação" (FERNANDES, 1980). Ele buscou sempre estar presente na teoria e prática social, agir não como um "funcionário" do sistema capitalista, mas como um "investigador", problematizando a luta de classes e enfim, questionando, criticamente, as grandes questões da vida social, econômica e política brasileira. Florestan Fernandes realizou, na prática, um exercício permanente de imaginação sociológica, buscando transformar grandes problemas vividos pelos trabalhadores em questões de relevância pública, em prol das transformações sociais (MILLS,1982). Para realizar este intento, seria imprescindível que, diante dos dados emergidos da realidade (incluindo os dados estatísticos oficiais), se realizasse uma reflexão filosófica, aqui concebida de natureza radical, rigorosa e de conjunto (SAVIANI, 2002). Isto implica, no entanto, superar a perspectiva do "empirismo abstrato",cujo objetivo principal é o desenvolvimento de pesquisas com base no fetiche dos "levantamentos estatísticos". Este processo pode ser chamado de "ritual estatístico", cujo produto culmina por adquirir valor mercantil junto às instituições de pesquisa, fundações etc., em detrimento de uma efetiva e "concreta" relevância pública (MILLS,1982). Pensando deste modo, o fetiche da "quantificação"e a obsessão pelo rigor das técnicas não possuem nenhuma correspondência com a importância das investigações para a sociedade, considerando que a maioria das perguntas e dos temas é medíocre, 
pois não se ancora em relevâncias do ponto de vista dos investigados (MINAYO, 2006, p.90). Aliado a tudo isso, urge, em termos de síntese dialética entre quantidade e qualidade, considerar a estatística como uma aliada e dado de caráter científico, social e político na perspectiva das problemáticas sociais, como é o caso da exploração do trabalho infantil; afinal [...] a precisão não é o único critério para a escolha do método e não deve ser confundida, como ocorre com frequência, com o "empírico"e o "verdadeiro"(MILLS,1982, p.82).

\section{As fontes estatísticas e os dilemas e dualismos entre quantidade e qualidade}

"As estatísticas simplificam tudo. As pessoas ficam felicíssimas com os índices" (SANTOS 2002).

Há um velho-novo debate nas ciências humanas e sociais sobre as dimensões qualitativas e quantitativas na produção do conhecimento. $\mathrm{Na}$ verdade, o dualismo entre o "cifrado" e o "decifrado", ou melhor, entre o "quantitativo"e o "qualitativo", tem uma história que remonta da baixa Idade Média, quando dominava o pensamento aristotélico. A "cifração" do social baseia-se na lógica formal, isto é, lógica redutora que reduz o real ao formal; apelando, portanto, à cifração, ou seja, reduzir, resumir, compendiar. Em contrapartida a esta perspectiva, circunscreve-se a busca da sociologia qualitativa por um contra movimento de "decifração". Este processo se encarrega da recuperação do real submergido às suas formas, contrapondo-se às lógicas passivamente demonstrativas que caracterizam algum positivismo, uma lógica da descoberta. Por outro lado, a sociologia qualitativa é uma sociologia que potencializa a "enigmatização do social" apontando "contradições". Neste sentido, "sem contradições não existem enigmas e sem enigmas não existem decifrações" (PAIS, 2003 p.131-132).

Neste emaranhado teórico-metodológico, há, de um lado, os adeptos do "dualismo epistemológico", que verifica entre quantidade e qualidade e, de outro lado, há aqueles que buscam uma síntese dialética entre quantidade e qualidade. Estas posições, grosso modo, estão situadas 
em três grandes abordagens, quais sejam: quantitativas (estatísticas), qualitativos (fenomenológico-hermenêuticas) e crítico-dialéticas (síntese dialética entre quantidade e qualidade).

Para Minayo (2007), a pesquisa qualitativa responde a questões muito particulares, preocupando-se, nas ciências sociais, com um nível de realidade que não pode ser quantificado ou mensurável. Isto significa dizer que ela trabalha com o universo de significados, motivos, aspirações, crenças, valores e atitudes, correspondendo, portanto, a um espaço mais profundo das relações, dos processos e dos fenômenos que não podem ser reduzidos à operacionalização de variáveis. Enquanto cientistas sociais que trabalham com estatística apreendem dos fenômenos apenas a região "visível, ecológica, morfológica e concreta", a abordagem qualitativa aprofunda-se no mundo dos significados das ações e relações humanas, um lado não perceptível e não captável em equações, médias e estatísticas.

Há, no entanto, neste imbróglio teórico-metodológico e ideológico, uma posição epistemológica que aposta numa "síntese dialética" e " falso dualismo" entre esses dois paradigmas de pesquisa (GAMBOA, 1995). Nesta lógica de pensamento, "o conjunto de dados quantitativos e qualitativos, porém, não se opõem". Pelo contrário, complementamse, pois a realidade abrangida por eles interage, dinamicamente, excluindo qualquer dicotomia.

Nas ciências humanas e sociais, o que se pode perceber, em linhas gerais, salvo exceções, é uma tendência para a defesa da pesquisa qualitativa, simultaneamente, em que há uma rejeição da pesquisa quantitativa. Esta perspectiva "não crítica" ou positivista, aborda os fenômenos, fazendo um recorte de cada fenômeno, delimitando-o e separando-o do contexto em que está sendo investigado. Opera sob a perspectiva das "variáveis" relacionadas com os entornos, denominadas "varáveis intervenientes". Estas são controladas, mantendo-as invariáveis e permanentes ou são ignoradas, isolando os fenômenos de seu ambiente natural, colocando-os em câmaras de experimentação, onde o ambiente e os contextos são controlados (GAMBOA, 2007; p.114).

A defesa do enfoque qualitativo pode ser vista, a princípio, como uma crítica fenomenológica ao conhecimento quantitativista (positivista), 
propondo-se um outro modelo de caráter mais "idealistasubjetivista"(ANDRÉ, 1991) de “enfoque subjetivistacompreensivista"(TRIVIÑOS, 1987), cujos pressupostos ontológicos e epistemológicos privilegiam os aspectos conscienciais, subjetivos dos atores, percepções, processos de conscientização, de compreensão do contexto cultural, da realidade a-histórica, da relevância dos fenômenos pelos significados que eles têm para o sujeito. Neste imbróglio epistemológico, emergem os chamados "enfoques críticoparticipativos com visão histórico-dialético", que buscam apreender a dialética da realidade social, da qual surge a necessidade de conhecer o "real" através de percepções, reflexões e intuições; buscando apreender as contradições, no sentido de transformá-las em processos contextuais, complexos e dinâmicos (LEFEVBRE,1975; TRIVIÑOS,1987).

Diante dessas três dimensões insurge aquilo que Gamboa (1995) chamou de "a procura de sínteses", em cujo processo pode-se dizer que há: a) uma postura mais radical ligada à crítica de toda essa tentativa de conciliação entre os modelos de pesquisa; b) há uma "segunda" reação ("síntese consensual"), que se caracteriza por admitir diferentes modalidades de trabalho e tolerar a coesão de modelos e a conveniência de trabalhar com formas qualitativas e quantitativas como um modo de " complementar" e "ampliar" informações com base em pontos de vista diferentes (pluralismo epistemológico); c) Por fim, há a "terceira" posição, assumida por alguns pesquisadores, que propõem uma síntese que supere os "falsos dualismos" ou as "dicotomias epistemológicas". Esses autores, diferentemente da segunda postura (pluralismo epistemológico), admitem a existência de diversos enfoques, à medida que numa espécie de continuum, sejam realizados por polarizações e problematizações das diversas perspectivas epistemológicas presentes na produção do conhecimento.

Como se pode perceber, há neste debate polêmico entre quantidade qualidade e, consecutivamente, sobre o uso das estatísticas nas pesquisas em ciências humanas e sociais, dimensões de caráter paradigmático e que extrapolam ao mero emprego da metodologia da pesquisa compreendida como mera "técnica". Trata-se de dimensões analíticas mais ampliadas e dialeticamente articuladas, cujo processo 
pode ser expresso por um "esquema paradigmático"(GAMBOA, 2007). O esquema paradigmático pode ser sintetizado a partir de seis níveis (ou pólos) que se articulam dialeticamente, a saber:1) Nível Técnico: fontes, técnicas de coleta, organização, sistematização e tratamento de dados e informações; 2) Nível Metodológico: abordagem de processos de pesquisa: formas de aproximação ao objeto (delimitação do todo, sua relação com as partes) e (des)consideração dos contextos; 3) Nível Teórico: fenômenos privilegiados, núcleo conceitual básico, autores e clássicos cultivados, pretensões críticas, tipos de mudanças propostas; 4) Nível Epistemológico: concepção de causalidade, de validação da prova científica e de ciência (critérios de cientificidade); 5) Pressupostos Gnosiológicos; maneiras de abstrair, generalizar, conceituar, classificar e formalizar, ou maneiras de relacionar o sujeito e o objeto. Critérios de construção do objeto científico; 6) Pressupostos Ontológicos: Categorias abrangentes e complexas, concepção de Homem, de Educação e Sociedade, concepções de realidade (Concepções de espaço, tempo e movimento), (GAMBOA,2007,p.72).

Em suma, como foi reiterado anteriormente, devido à dinâmica multidisciplinar e complexa dos fenômenos sociais, no caso as estatísticas oficiais, creio que debater quantidade e qualidade implica compreender esta relação como um "continuum", a partir da superação do atual estágio de polarizações mediante sínteses consensuais de diálogo entre os paradigmas. Isto significa, elaborar uma síntese diferente da visão intersubjetiva e para além do dualismo epistemológico, ou seja, [...] requer uma síntese entre as polarizações, que parte da aceitação da contradição entre esses pólos, realizando um processo de passagem de um pólo para outro. Neste sentido, uma nova concepção de síntese (dos contrários), a partir do enfoque críticodialético, busca escapar do chamado pluralismo epistemológico, buscando, assim, a superação dos pontos conflitantes que acontecem, tendo em vista o processo de aquisição de novas formas em que se assimilam as características negadas e afirmadas na passagem de um extremo ao outro (GAMBOA,1995,p.100-102).

Todos esses desafios podem ser considerados se abstrairmos as relações entre estatística e história no processo de construção do conhecimento. Isso implica levarmos em conta que: a) A estatística 
tem necessidade da história; é a história que esclarece as regularidades de sucessão; b) A estatística, distingue os fatos de constância dos fatos de variação, permitindo ao sociólogo saber qual a direção que deve seguir para encontrar a explicação das regularidades que ela lhe oferece, entre fatores históricos ou entre os extra-históricos; c) $\mathrm{O}$ historiador não pode dispensar, quando isso é possível, a referência aos dados estatísticos, os quais possibilitam elucidar melhor as causas reais dos fenômenos que a crítica dos testemunhos lhe permitiu elaborar (BASTIDE,1994). Trata-se, portanto, de uma relação histórico-dialética entre consenso e conflito.

Nesta mesma direção, é preciso pensar, também, que os sociólogos e semiólogos ainda examinam muito pouco as estatísticas no cotidiano. Talvez seja pelo fato de se deixarem impressionar por toda a maquinaria que está por trás delas; porque compartilham dos preconceitos do público a seu respeito e que, por isso mesmo, não a vêem como objeto de estudo (JOURNET apud BESSON,1995, p.257-261).

\section{Concluindo para "começar de novo"... e colocando mais "lenha na fogueira"}

As conclusões provisórias às quais cheguei consideram, primeiramente, as pesquisas realizadas por Viella (2010), Liebel (2003), Viella e Conde (2010) e Garcia (2010). Em seguida, consideram as reflexões teórico-metodológicas acerca dos pressupostos ontológicos, epistemológicos que sustentam os paradigmas quantitativo e qualitativo, assim como o uso político das estatísticas.

Há uma confusão entre a palavra "diminuição" e "erradicação". A primeira evoca os sentidos e significados presentes em ações das políticas públicas de causa e efeito (Bolsa família). Diminuição significa uma instabilidade e que esses dados podem, a depender de outros fatores (política econômica, planos de ajuste etc.), tranquilamente reincidir e voltar a estaca zero, em face do caráter precário e emergencial das ações. Ao passo que "erradicação" significa "cortar o mal pela raiz", enfim, acabar! Porém, essa tarefa torna-se impossível se não se erradicar, primeiramente, as bases do modo de produção capitalista que sustentam a economia política (SILVA, 2003, p.153). 
Essas ideias e práticas atingem de forma peremptória as políticas públicas brasileiras. Nesse aspecto, as políticas públicas do atual governo, em articulação com alguns sindicatos, associações, movimentos sociais e ONGs, foram literalmente cooptados ${ }^{9}$, aderindo à lógica do projeto neoliberal. Essa parcela da sociedade civil deixou, de forma conformista, amoldar suas consciências aos mitos e fetiches das estatísticas e das mudanças de caráter emergenciais das políticas públicas (SILVA, 2007). O que se perceber nisso tudo, quando se investiga os documentos (mapas, dados estatísticos e discursos) acerca da exploração de crianças e jovens, é um tom profético e de triunfalismo acerca do fim da divisão entre as classes sociais. Esta faceta pode ser observada na forma como está sendo veiculada o fim da miséria na mídia. Por exemplo, na folha de São Paulo (13/06/2010), o texto, a partir das palavras do economista chefe do Centro de Pesquisas Sociais-FGV-Rio, diz em tom profético "Brasil deve cortar a pobreza à metade até 2014". O texto conclui, num misto de leviandade e ideologia, afirmando: "Mantida a tendência de crescimento médio da economia do governo Lula, o Brasil cortará pela metade o número de pessoas pobres pela metade até 2014".

Diante de tantas contradições, erradicar ("pela raiz") qualquer tipo de exploração humana significa destruir o modo de produção capitalista e em seu lugar construir uma "sociedade para além do capital", digo, para além da divisão abissal das classes sociais, da propriedade privada, do mercado etc. Neste processo, seria importante ter clareza dos pressupostos ontológicos, epistemológicos e ideológicos da "educação para além do capital". Nessa lógica, educar não é mera transferência de conhecimento, mas sim conscientização e testemunho de vida, educar é construir, libertar o ser humano das cadeias do determinismo neoliberal a partir do reconhecimento que a história é um campo aberto de possibilidades (MÉSZÄROS, 2005).

Para construir uma sociedade para além do capital, significa construir uma sociedade socialista, ou melhor, "neo-socialista" (IANNI, 2005), cujos procedimentos revolucionários poderiam ser: protestar e lutar contra as desigualdades e contradições sociais, engendradas socialmente e que envolvem as relações trabalho e capital, mulher e 
homem, negro e branco, nativo e conquistador, sociedade e natureza. Além disso, trata-se, simultaneamente, de organizar, conscientizar, lutar pela transformação das condições sociais, econômicas, políticas e culturais, sob as quais se produzem e, com frequência, também se agravam as desigualdades, tensões e contradições que atravessam os mais diversos círculos de relações sociais em todo o planeta (IANNI, 2004). Porém, tal tarefa implica uma crítica e autocrítica à banalização da teoria e prática do socialismo, principalmente, ao socialismo maquiado de liberalismo. Isto implica a "necessária retomada do tema da transição" que implica reflexão sobre como o processo de acumulação do capital vem, ao longo da história, produzindo riqueza abstrata. Nestes termos, "para defender a humanidade", é preciso superar esta forma de organização social voltada para a multiplicação de riqueza abstrata (BENJAMIM, 2003). Neste caso, uma das tarefas plausíveis e não a única, da luta dos pesquisadores-militantes, é o enfrentamento ideológico e intelectual, no sentido de desconstruir o fetiche dos números; de ser "contra o uso político das estatísticas" (SANTOS, 2002), que tem como consequência a lógica da reprodução e perpetuação do capital.

Na contramão dos discursos e das estatísticas oficiais dotados de ideologia do "uso político das estatísticas" (SANTOS, 2002), seja para a exploração do trabalho de crianças e jovens no Brasil, seja para o caso da cana-de-açúcar, urge considerar, para se contrapor aos dados oficiais, outros dados de caráter tanto quantitativo quanto qualitativo. Estou me referindo ao "aviltamento do trabalho", cujo espetáculo se esparrama por todas as partes (ANTUNES, 1999, 2007, 2008). Isto significa, admitir, segundo o autor, que há um enorme contingente de pessoas, "incluídas até a medula" (FORRESTER,1997) no trabalho precário, além de exemplos de trabalho escravo no campo, nos rincões do latifúndio. Acerca disso, pode-se enunciar a degradação do trabalho imigrante, especialmente boliviano, nas empresas de confecção em São Paulo. Jornadas de até 17 horas diárias em troca de casa e comida, ou seja, trabalho imigrante no limite da condição degradante e insalubre. Outros exemplos podem ser dados: "chicanos" nos EUA, decasséguis no Japão, "gastarbeiters" na Alemanha, "lavoro nero" na Itália, 
"brasiguaios" no Paraguai - a lista não termina por aqui. Isso tudo sem falar dos desempregados do Leste Europeu que invadem o "pequeno canto do mundo" ocidental em busca dos restos do labor. Há indicações da mudança do fluxo migracional, fazendo com que os deserdados do Sul tentem, dramaticamente, furar os bloqueios do Norte, cujo exemplo mais abjeto é o muro da vergonha que separa os EUA do México.

Quanto a esse respeito, "há uma autêntica conquista da chamada globalização: enquanto os capitais migram com velocidade mais ágil que a dos foguetes, o trabalho deve mover-se no passo das tartarugas".

Como se vê, os exemplos são infindáveis. Os capitais transnacionais livres e trabalhadores nacionais cativos, num mundo cada vez mais maquinal, informacional e digital, forjam o chamado "cybertariado", ou seja, o trabalhador qualificado da era da cibernética que vivencia as condições do velho proletariado. Nesta mesma direção, a informalização dada pela perda de liames contratuais de trabalho, vem aumentando em escala global, num contexto de ampliação de todas as formas de precarização e terceirização. Isso tudo termina por gerar as mais diferentes formas de trabalho precário, as quais se desenvolvem com a chamada polivalência da era flexível ${ }^{10}$. Uma prova disso é que no Japão, jovens operários migram em busca de trabalho nas cidades e dormem em cápsulas de vidro do tamanho de um caixão. São os operários encapsulados. Do outro lado do mundo, na nossa América Latina, encontramos trabalhadoras domésticas (mulheres e crianças) que atingem a jornada semanal de 90 horas de trabalho, com um dia de folga ao mês, numa era em que poderíamos trabalhar dez vezes menos, se a lógica predominante não fosse tão destrutiva para a humanidade que depende de seu trabalho para sobreviver (ANTUNES, 2008).

De acordo com o autor, essa é a realidade concreta do mundo do trabalho na atualidade. Somando-se a todo esse quadro de precarização, crescem com bastante força os "trabalhos voluntários". Hoje, muitos trabalhadores para obterem empregos são, praticamente, "obrigados" a realizarem trabalhos "voluntários". E isso sem falar na explosão do número de estagiários (o "escraviários") $)^{11}$, candidatos prestes a roubar um trabalho efetivo com remuneração de escravo. Há, ainda, nesta perspectiva: a) as diversas manifestações de 
desigualdade de gênero, fato este que leva, ainda, as mulheres trabalharem mais, com menos direitos e reduzida remuneração; b) as diferenciações étnicas e raciais, em cujo cerne se amalgamam o racismo e as imbricações entre classe, raça/etnia.

Por fim, contrariando o discurso que profetiza um "capitalismo humanizado", a ideologia da "responsabilidade social das empresas" (PFEIFER, 2006; SILVEIRA, 2007) ${ }^{12} \cdots$, da inclusão social e da cidadania, cresce em escala global a precarização do trabalho com os seus altos índices de trabalho degradado, isto é, "a crescente inclusão de crianças no mercado de trabalho global, nos países latinoamericanos, asiáticos, africanos, bem como nos países centrais, como EUA, Inglaterra, Itália, Japão, sem falar na China, Índia etc." (ANTUNES, 2008). Essa nova "morfologia do trabalho" é forjada no processo de reestruturação produtiva das políticas neoliberais e do cenário de desindustrialização e privatização. Em consequência disso, um terço da força humana de trabalho, disponível em escala planetária, ou se encontra exercendo trabalhos parciais, precários, temporários, ou já vivenciava a barbárie do desemprego. Neste contexto, existe mais de um bilhão de homens e mulheres que estão padecendo das vicissitudes do trabalho precarizado, instável, temporário, terceirizado, quase virtual, entre os quais se encontram centenas de milhões, tendo o seu cotidiano moldado pelo desemprego estrutural (ANTUNES, 2007).

Como se pode perceber, não importa que o trabalho adulto se torne supérfluo e que muitos milhões de homens e mulheres em idade de trabalho vivenciem o desemprego estrutural. Mas os meninos e meninas ${ }^{13}$ devem, desde muito cedo, fazer parte do ciclo produtivo: seu corpo brincante transfigura-se muito precocemente em corpo produtivo para o capital. Nesta mesma perspectiva, em outro livro intitulado "A desertificação neoliberal no Brasil”, Antunes (2005) nos apresenta subsídios para a compreensão das consequências e repercussões mais nefastas do neoliberalismo em nosso país.

Esses dados parecem não comover aqueles cujas consciências estão amoldadas à "lógica exclusiva da racionalidade econômica e da valorização do capital, ou aqueles que não levam em conta a nova "morfologia do trabalho", ao celebrarem a vitória da diminuição dos 
números ou do suposto "desaparecimento" total da exploração do trabalho infantil em algumas regiões do Brasil (canaviais de Pernambuco) e outras, sem levar em conta essa "nova morfologia do trabalho". Essas constatações nos levam a concluir que, o que está na "ordem do dia", é "instaurar a caridade como política, porque a redução "natural" dos empregos e dos salários justifica a necessidade de políticas "compensatórias", produzidas pelo "neoliberalismo social" ou "capitalismo humanizado" para corrigir "excessos" do liberalismo econômico (CASTRO, 2003, s/p; VIELLA, 2008, p.152).

Diante da produção de mitos que geram fetiches, presentes nos discursos ideológicos e dados estatísticos, só nos resta como intelectuais, intensificar cada vez mais uma crítica radical e rigorosa ao neoliberalismo social. Esta, deve trazer, subjacente, uma certa dose de "pessimismo radical". Tal pessimismo se constitui um dever civil, uma vez que só um pessimismo radical da razão, pode despertar com uma sacudidela aqueles que, de um lado ou de outro, ainda não se deram conta que o sono da razão gera monstros (BOBIO apud GENTILI, 1998, p. 114). Em outras palavras, os otimistas são aqueles que acham que tudo está ótimo e que, portanto, não querem mudar o mundo. Em contrapartida, os pessimistas são aqueles que querem mudar o mundo (SARAMAGO, 1997).

Concluo com minha porção de pessimismo radical, tendo como mote as palavras pertinentes e peremptórias de Viviane Forrester (1997, p. 15):

(...) Ao ver como se pregam e se jogam homens e mulheres em virtude de um mercado de trabalho errático, cada vez mais imaginário, comparável àquela "pele de onagro" que se encolhe, um mercado do qual eles dependem, do qual suas vidas dependem, mas que não depende deles; ao ver como já não são contratados (grifos meus) com tanta frequiência, e como vegetam em particular os jovens (grifos meus), numa vacuidade sem limites, considerada degradante, e como são detestados por isso; ao ver como, a partir daí, a vida os maltrata e como a ajudamos a maltratá-los; ao ver que, para além da exploração dos homens, havia algo ainda pior: a ausência de qualquer exploração - como deixar de dizer que, não sendo sequer exploráveis (grifos meus), nem sequer necessárias 
à exploração, ela própria inútil, as multidões podem tremer, e cada um dentro da multidão? [...] Então como um eco aquela pergunta: “Será útil viver quando não se é lucrativo ao lucro?", ela própria eco daquela outra: "É preciso merecer viver para ter esse direito? Surge o temor insidioso, o medo difuso, mas justificado, de ver um grande número de seres humanos considerados supérfluos (grifos meus). Não subalternos nem reprovados: supérfluos. e por essa razão, nocivos (grifos meus). E por essa razão... [...] incluídos até a medula...

\section{Notas}

${ }^{1}$ Professor do Centro de Desportos/Departamento de Educação Física da Universidade de Santa Catarina. E-mail: mauran@uol.com.br

${ }^{2}$ Refiro-me, respectivamente, à Tese de Douramento "O Assalto à infância no mundo amargo da cana-de-açúcar. Onde está o lazer? O gato comeu" (2000), cujo texto se converteu no livro "Trama Doce Amarga (Exploração do) Trabalho Infantil e Cultura Lúdica" (2003).

${ }^{3}$ Esta problemática,merece um estudo empírico e dos dados desta região,pois, de acordo com a FETAPE-Federação dos Trabalhadores da Agricultura de Pernambuco e com o Fórum Estadual de Erradicação do Trabalho Infantil de Pernambuco, "não é possível ver mais criança trabalhando na cana",em razão da fiscalização ostensiva do Ministério do Trabalho e Emprego e do Programa Bolsa Família.Ver a esse respeito, o "Plano Estadual de Prevenção e Erradicação do Trabalho Infantil em Pernambuco"(2008),em parceria com o Conselho Estadual de Defesa dos Direitos da Criança e do Adolescente de Pernambuco - CEDCA e a Secretaria Desenvolvimento Social e Direitos Humanos do Governo de Pernambuco - SDSDH".

${ }^{4}$ Críticas do Deutsche NRO-Forum Kinderabeit" ("Fórum de ONGs alemãs sobre o Trabalho Infantil").

${ }^{5}$ Pesquisador colaborador do IFEJANT (Instituto de Formación para Educadores de Jóvenes, Adolescentes y Niños Trabajadores) da América Latina e Caribe. (IFEJANT). O IFEJANT é uma rede de organizações que divulga pesquisas sobre o movimentos de crianças e adolescentes trabalhadores de diversos quadrantes do mundo como Alemanha, Bélgica, Itália, Índia, Nepal e outros.

${ }^{6} \mathrm{O}$ trabalho socialmente necessário (trabalho abstrato), é a substância do valor e sua medida se faz em unidades de tempo (tempo socialmente necessário) (MARX,2003, p.48).

${ }^{7}$ Intitulei as minhas incursões no campo canavieiro como "eventos-campos" (Silva, 2000; SILVA).

${ }^{8} \mathrm{O}$ espaço das atividades pedagógicas; espaço do brincar: cantinhos da higiene e cantinho da história; são terminologias utilizadas pela professora da sala e consideramos utilizálos para sermos fidedignas aos dados coletados e as análises.

${ }^{9}$ Quanto a esse respeito Antunes citando Bernardo (1999, p.188-189), ao abordar o tema da "crise do movimento operário e a centralidade do trabalho hoje", afirma que já 
a partir dos anos 70, começou um agudo "processo político e ideológico de socialdemocratização da esquerda e sua consequente atuação subordinada à ordem do capital". Tal processo atingiu fortemente amplos setores da esquerda sindical e partidária, repercutindo na classe trabalhadora. Assim, o sindicalismo de esquerda passou a recorrer frequentemente à institucional idade e a burocratização, que baseiam ao projeto da social-democracia sindical.

${ }^{10}$ Este termo merece o mesmo juízo crítico do banalizado termo flexibilização, conceito puramente descritivo e prescritivo, a um só tempo, utilizado de modo eufemístico pelos técnicos da ordem estabelecida para "naturalizar" a mercantilização completa das relações de trabalho, base da insegurança institucionalizada (CASTRO, 2003[s/p]).

${ }^{11}$ Cf.www.skywalker.com.br

12 A responsabilidade social das empresas traz em seu bojo aspectos como ética cidadania e direitos humanos. Sua atuação assenta-se na conscientização dos indivíduos e instituições, construindo sentimentos de responsabilidade e solidariedade social. Dessa maneira, "as empresas são impelidas a colocarem-se como parceiras e corresponsáveis pelo desenvolvimento social de forma estruturada, dando tratamento semelhante e colocando à disposição o mesmo know how que utilizam em suas atividades fins" (PFEIFER, 2006, p.13). No entanto, partimos do pressuposto de que a responsabilidade social das empresas apenas representa uma proposta funcionalista, uma vez alocada no âmbito do capital, consolidando-se como uma das estratégias utilizadas pelas empresas capitalistas na gestão de seus negócios.

${ }^{13}$ Ver sobre a exploração do trabalho infantil das meninas na cana-de-açúcar e o trabalho doméstico (SILVA, 2002).

\section{Referências}

\section{ANDRÉ, Marli E.A. Técnicas Qualitativas e cuantitativas de pesquisa: Oposição ou Covergência? São Paulo: Cadernos do CERU, USP, no.3-Série II, 1991.}

ANTUNES, R. Os sentidos do trabalho: ensaio sobre a afirmação e a negação do trabalho. São Paulo: Boitempo, 1999.

.A trajetória (e a tragédia) do PT. In: Antunes, R. Adesertificação neoliberal no Brasil (Collor, FHC e Lula). São Paulo: Autores Associados, 2005. p. 164-167.

. Dimensões da precarização estrutural do trabalho. In:DRUCK, Graça e FRANCO,Tânia. A perda da razão social do trabalho. São Paulo: Boitempo, 2007.

O que temos a comemorar? Folha de São Paulo, 02/05/2008.

\footnotetext{
ARRUDA, Marcos. ONGs e o Banco Mundial; é possível colaborar criticamente? In:DE TOMASI,L.ET; WARDE, M. HADDAD, S. O Banco Mundial e as Políticas Educacionais. São Paulo:Cortez,1996.
} 
BASTIDE, Roger e QUEIROZ, Maria Isaura (Org.). Bastide: Ensaios e Pesquisas.São Paulo: Cadernos do CERU/USP,1994.

BENJAMIM, César. MARX e o Socialismo. São Paulo: Expressão popular, 2003.

BESSON, Jean Louis. As Estatísticas: Verdadeiras ou Falsas? In: BESSON, JeanLouis. A ilusão das Estatísticas. São Paulo:Universidade Estadual Paulista,1995.

BIANCHETTI, Lucídio. Curriculum Vitae em tempos de empreendedorismo e empregabilidade. In; AUED, Bernadete(Org.). Traços do Trabalho Coletivo. São Paulo: Casa do Psicólogo, 2005.

BRUYNE, Paul de (Org.). Dinâmica da Pesquisa em Ciências Sociais. Rio de Janeiro: Ed. Francisco Alves, 1991.

CARVALHO, Inaiá Maria M. O trabalho infantil no Brasil contemporâneo. Salvador: Cadernos CRH, set/Dez. 2008.

CASTRO, Ramón Pena. Novamente sobre a questão do trabalho. Trabalho necessário: UFRJ, ano 2003. <Disponível em http://www.uff.br/ trabalhonecessario>. Acesso em: 01 de agosto de 2010.

CHAUÍ, Marilena. Convite à Filosofia. São Paulo: Ática, 1995. 09/05/1999.

. A Universidade Operacional. Folha de São Paulo, Caderno Mais, A Universidade sob nova perspectiva. Conferência de Abertura da ANPED, Poços de Caldas, 05/10/2003.

CHOMSKY, N. Segredos, Mentiras e Democracia. Brasília: Ed. UNB, 1997.

CHOSSUDOVSKY, M. A Globalização da Pobreza: Impactos das reformas do FMI e do Banco Mundial. São Paulo: Moderna, 1999.

CONDE, Soraya F. Trabalho Invisível. Florianópolis, SC. 2007. Dissertação (mestrado em Sociologia Política). Programa de Pós-graduação em Sociologia Política/CFH. Universidade Federal de Santa Catarina.

DURKHEIM, Émile. As Regras do Método Sociológico. 6.ed. São Paulo: Nacional, 1971. 
DEBORD, Guy. A sociedade do espetáculo: comentários sobre a sociedade do espetáculo. Rio de Janeiro: Contraponto,1997.

FABRA, Paul. A Economia cega: Entrevista com Paul Fabra. In: BESSON, Jean-Louis. A ilusão das Estatísticas. São Paulo: Universidade Estadual Paulista,1995.

FORRESTER, V. O horror econômico. São Paulo: Edunesp, 1997.

FERNANDES, Florestan. A Contestação Necessária. São Paulo: Ática, 1995.

FERNANDES, Florestan. A Sociologia no Brasil. Petrópolis, RJ: Vozes, 1980.

GAMBOA, Silvio S. e SANTOS FILHO, José Camilo (Org.). Pesquisa Educacional: Quantidade-Qualidade. São Paulo: Cortez,1995.

GAMBOA, Silvio S. Pesquisa em Educação: Métodos e Epistemologias. Chapecó: Argos, 2007.

GARCIA, Enrique Jamamarillo M. Una extraña dictadura amenaza a nível global a los niños, niñas y adolescentes trabajadores. Revista pedagógica, $\mathrm{N}^{\circ}$. 24, Jan/junho, 2010.

GALEANO, E. De Pernas proAr: A escola do Mundo ao Avesso. Porto Alegre: L\&PM, 1999.

GENTILI, Pablo.A falsificação do Consenso:Simulacro e imposição na reforma educacional do neoliberalismo. Petrópolis,RJ:Vozes, 1998.

GIROUX, Henri. Escola crítica e política cultural. São Paulo: Cortez; Autores Associados, 1987.

HARVEY, David. A Condição Pós-Moderna. São Paulo: Loyola 1ª ed., 1998.

IANNI, Octavio. Capitalismo, Violência e Terrorismo. Rio de Janeiro: Civilização Brasileira, 2004.

KOSIK, Karel. Dialética do Concreto. Rio de Janeiro : Paz e Terra, 1976. 
LEFEBVRE, Henri. Lógica Formal e Lógica Dialética. Rio de Janeiro: Civilização Brasileira; 1975.

LIEBEL, Manfred. História de exito o desorientación? El nuevo informe de La OIT sobre El trabajo infantil. In:NATs (Revista internacional desde Niños y Adolescentes Trabajadores), Año VII, n.15, p.174-179, set. 2006.

LIEBEL, Manfred. Repensar a mirada adulta. Pobreza infantil, trabajo infantil y nueva subjetividad de la infância. In:NATs (Revista internacional desde Niños y Adolescentes Trabajadores), Año VII, n.15, p.174-179, set. 2003.

LÖWY, Michael. Ideologia e Ciência Social. Elementos para uma Análise Marxista. 7a ed., São Paulo: Cortez, 1991

MARX, Karl. O capital: crítica da economia política. Rio de Janeiro: Civilização Brasileira, 2003.

MELLILIÉ, Dominique. Suicídios: Modos de Registro. In: BESSON, JeanLouis. A ilusão das Estatísticas. São Paulo: Universidade Estadual Paulista,1995.

MÉZÁROS, István. A educação para além do capital. São Paulo: Boitempo, 2005.

MILLS, Wright C. A imaginação Sociológica. Rio de Janeiro: Zahar, 1982.

MINAYO, M.C.S. O desafio do conhecimento: pesquisa qualitativa em Saúde. Rio de Janeiro - São Paulo, ABRASCO-HUCITEC, 2007.

PAIS, José Machado. Vida Cotidiana: enigmas e revelações. São Paulo: Cortez Editora, 2003.

PETRAS, James. O papel dos intelectuais na transformação social. In: RAMPINELLI, Waldir José. Universidade: A Democracia Ameaçada. São Paulo: Xamã, 2005.

ORGANIZAÇÃO INTERNACIONAL DO TRABAHO. Bibliografia sobre o Trabalho de crianças e Adolescentes no Brasil. São Paulo: Secretaria da Criança, Família e Bem-Estar Social, 1994. 
PFEIFER, Mariana. Responsabilidade Social das empresas: instrumento de consolidação hegemônica do projeto neoliberal? Florianópolis, 2006. Dissertação de Mestrado. Universidade Federal de Santa Catarina. Centro Sócio-Econômico. Programa de Pós-Graduação em Serviço Social.

RICHARDSON, Roberto Jarry et al. Pesquisa Social; Métodos e Técnicas. São Paulo; Atlas, 2010.

SAINT-GEORGES. Pesquisa e crítica das fontes de documentação nos domínios econômico, social e político. In: ALBARELLO, L. et al Práticas e métodos de investigação em Ciências Sociais. Portugal: Gradiva, 1997.

SANTOS, Milton. Contra o uso político das estatísticas. In: SANTOS, Milton. Org.por RIBEIRO,W. C. O País distorcido: O Brasil, a Globalização e a Cidadania. São Paulo: Publifolha, 2002.

SAVIANI, Dermeval. Educação: Do Senso-Comum à Consciência Filosófica. Campinas, SP: Autores Associados, 2002.

SARAMAGO,José.Entrevista concedida à Folha de São Paulo,Ilustrada,18/11/ 1997.

SILVA, Maurício R. O assalto à infância no mundo amargo da cana-de-açúcar: onde está o lazer? O gato comeu? Tese de Doutorado. Campinas: UNICAMP Departamento de Ciências Sociais Aplicadas à Educação, 2000.

. Trama Doce-Amarga: (Exploração do) Trabalho Infantil e Cultura Lúdica. IJUÍ: Ed. UNIJUÍ; São Paulo; HUCITEC, 2003.

. Recortando e colando as imagens da vida cotidiana do trabalho e da cultura lúdica das meninas-mulheres e das mulheres-meninas da zona da mata canavieira pernambucana. Cadernos Cedes. Campinas, ano XXII, n. 56, p.23-52, abr. 2002.

. Entre a visibilidade e a banalização: a celebração da infância no mundo ou festival mercadológico do The nited Collors of Benetton. In: LEITE, Maria Isabel (Org.). Ata e desata: partilhando uma experiência de formação continuada. Rio de Janeiro: Ravil, 2002b. v. 1. 
SILVA, Maurício R(Org.). Políticas públicas Para o Esporte: Cidadania e Inclusão Social. In: SILVA, Maurício R. Esporte, Educação, Estado e Sociedade: As políticas Sociais em Foco. Chapecó: Argos, 2007.

SILVEIRA, Juliano. Desenvolvimento Humano, Responsabilidade social e educação no Capitalismo: Investigando o Programa "Educação pelo Esporte" do Instituto Ayrton Senna. Florianópolis, 2007, 155 fls. Dissertação de Mestrado. Universidade Federal de Santa Catarina. Centro de Desportos. Programa de Pós-Graduação em Educação Física.

THÉVENOT, Laurent. Cifras que falam: Medida Estatística e Juízo Comum. In:BESSON, Jean-Louis. A ilusão das Estatísticas. São Paulo: Universidade Estadual Paulista,1995.

TONET, Ivo. Educação,Cidadania e emancipação Humana. Ijuí; Unijuí, 2005.

TRIVIÑOS, Augusto N. Introdução à pesquisa em Ciências Sociais: A pesquisa Qualitativa em Educação. São Paulo: Atlas, 1987.

VIELLA, Maria dos Anjos L. Fetichismo da Infância e do trabalho infantil nos mapas do trabalho infantil. Tese de Doutorado defendida no Centro de Ciências da Educação. Florianópolis:Universidade Federal de Santa Catarina, 2008.

VIELLA, M. A.L. ; CONDE, S. F . O mito da redução da exploração do trabalho infantil no Brasil e em Santa Catarina. In: VI Congreso de la Asociación Latinoamericana de sociologia del trabajo, 2010, México.

VERA, Asti. Metodologia da Pesquisa Científica. Porto Alegre; Globo,1973.

WADA, Ronaldo e VIEIRA, Sonia. O que é Estatística. São Paulo: Brasiliense, Coleção Primeiros Passos, 1998.

WEBER, Marx. A Objetividade do conhecimento na ciência social e política. Campinas, SP : Ed. UNICAMP, 1992, Vol.1, p.104-154. UFSC. Centro de Ciências da Educação, Núcleo de Publicações, 1999. 


\section{Abstract: \\ Theoretical and methodological reflections on the datas from the exploitation of child labor: Or how to turn children and young people in numbers}

This text is due to the multidimensionality of the problem, formulating questions, searching for possible answers to the "dance of numbers" statistical official agencies, focusing not necessarily the centrality of text in the statistical analysis of absolute numbers and in more dense qualitative. The intent is to instigate the academic community, public policy, and social movements and unions, with more questions than answers, to problematize the numbers on the labor exploitation of children and youngs. For that, I take as reference some research previously produced: (LIEBEL, 2003, 2006; VIELA, 2008, VIELLA; CONDE , 2010; GARCIA, 2010; SILVA, 2003) seeking to make theoretical, methodological reflection, of a more "theoretical and practical" in terms of concrete examples of critical analysis already performed The conclusions reached indicate a challenge to specialists from the university and also for those who are outside, on the need to overcome the "false dualism" between quantity and quality; in the direction of qualified and critical analysis of official statistics and " against the political use of statistics "about the exploitation of child labor, in short, against manipulation of data for electoral and ideological under the" social neoliberalism."

Keywords: Child labor. Exploitation. Statistics. Eradication. Public policy.

Recebido em dezembro de 2009.

Aceito em maio de 2010. 